This is an electronic reprint of the original article. This reprint may differ from the original in pagination and typographic detail.

Author(s): Kivistö, Jussi; Pekkola, Elias; Siekkinen, Taru

Title: $\quad$ Latest reforms in Finnish doctoral education in light of recent European developments

Year: $\quad 2017$

Version:

Please cite the original version:

Kivistö, J., Pekkola, E., \& Siekkinen, T. (2017). Latest reforms in Finnish doctoral education in light of recent European developments. European Journal of Higher Education, 7(3), 291-308. https://doi.org/10.1080/21568235.2017.1290881

All material supplied via JYX is protected by copyright and other intellectual property rights, and duplication or sale of all or part of any of the repository collections is not permitted, except that material may be duplicated by you for your research use or educational purposes in electronic or print form. You must obtain permission for any other use. Electronic or print copies may not be offered, whether for sale or otherwise to anyone who is not an authorised user. 
Latest reforms in Finnish doctoral education in light of recent European developments

Published in European Journal of Higher Education online 21 February 2017. https://doi.org/10.1080/21568235.2017.1290881

Jussi Kivistö*

corresponding author

Faculty of Management, University of Tampere, Finland

jussi.kivisto@uta.fi, +358456751709

Elias Pekkola

Faculty of Management, University of Tampere, Finland

elias.pekkola@uta.fi

Taru Siekkinen

Finnish Institute for Educational Research, University of Jyväskylä, Finland taru.siekkinen@jyu.fi 


\section{Latest reforms in Finnish doctoral education in light of recent European developments}

Doctoral education as a policy field is an important link between educational, research and innovation policies. It is gaining importance in European and national policy discussions. Doctoral education policies are increasingly formulated at the supranational level, as the European Commission does not possess formal competence in terms of authority over the educational policies. Consequently, policy steering is mostly performed at the national level. In this article, we examine Finnish doctoral education from the steering perspective in a European framework. We describe the development and steering of Finnish doctoral education, as well as the current doctoral education policies and instruments used to implement it. We analyse the main steering documents of Finnish doctoral education policy and provide insights into the implementation of the European doctoral education agenda through a case study from the University of Jyväskylä. We argue that directing policy in terms of information is the most important instrument for developing doctoral studies. Furthermore, supranational steering directly affects Finnish higher education institutions.

Keywords: doctoral education, policy instruments, steering, higher education policy, implementation

\section{Introduction}

Doctoral training has become an important progenitor of new knowledge, which is crucial to the development of prosperous, developed societies, as they must rely on new knowledge and highly skilled knowledge workers to feed the process of continuous innovation (European Commission 2011). Doctoral graduates play a key role in this development, for two reasons: (1) they are specifically trained for research, even if additional training is increasingly required after their doctoral studies through postdoctoral positions; and (2) obtaining a degree at the highest level of education is believed to provide the best qualifications for the creation, implementation, and diffusion of knowledge and innovation (Auriol 2010). Hence, the importance of doctoral education has increased, especially in Europe (Kehm 2007a). 
At the European level, the role of the European University Association (EUA) in promoting the development of doctoral education has been pivotal over the past decade. As the main representative of European higher education institutions, the EUA has launched a series of activities aimed at the development, advancement, and improvement of doctoral education and research training in Europe. As one of the major outcomes of these activities, and by building on the conclusions and recommendations of the 2005 Bologna seminar on 'Doctoral Programmes for the European Knowledge Society', the EUA published the 'Salzburg II Recommendations' in 2010, which have become widely endorsed as guidelines for developing doctoral training in Europe. These recommendations highlight, among others, the importance of critical mass and diversity of research, recruitment, the admission and status of doctoral students, the quality and accountability of programmes, sustainable funding, and the institutional autonomy of universities (European University Association 2010). In line with the EUA recommendations, the European Commission has also highlighted the importance of developing doctoral education by summarising 'best practices' for innovative doctoral training, focusing on themes such as research excellence, an attractive institutional environment, interdisciplinary research options, exposure to industry and other relevant employment sectors, international networking, transferable skills training, and quality assurance (European Commission 2011).

In parallel with wider European developments, reforming doctoral education has been one of the most important topics of Finnish higher education policy over the past decade. For instance, the Finnish Higher Education Evaluation Council (FINHEEC, now renamed the Finnish Education Evaluation Centre [FINEEC]), the national higher education quality assurance body, ordered an international review in 2005-2006 (Dill et al. 2006), which provided several recommendations for developing Finnish doctoral training. In 2011, FINHEEC prepared a follow-up review that investigated the implementation of the earlier 
review's recommendations and the current state of doctoral education (Niemi et al. 2011). At the same time, the Academy of Finland (a national research funding organisation) published a review, the so-called 'Ruskoaho Report,' which included a series of reform initiatives for Finnish doctoral education (Suomen Akatemia 2011). These two reviews led to the initiation of a series of comprehensive reforms in Finnish doctoral education programmes alongside other relevant but broader focused policy documents such as the policy report on the fourstage career model (Opetusministeriö 2008).

Despite the importance of the topic, few Finnish studies have focused on the reform processes of doctoral education and, in particular, on discovering the underlying dynamics affecting these processes. Few previous studies have discussed the development of Finnish doctoral training in light of international influences and perspectives (Kivinen, Ahola, and Kokko 1999; Ahola 2007; Kivistö 2011). None has covered the latest European trends and principles in the development of doctoral training. Similarly, at the European level, few studies have analysed the latest reforms in doctoral training.

The objective of this paper is to address existing knowledge gaps by exploring how and to what extent Finnish reforms in doctoral education are aligned with the latest Europeanlevel recommendations and to what extent the perceived level of alignment could be explained by the government's use of policy instruments. We aim to achieve this objective as follows: We first outline the European context of the development of doctoral education, by focusing on the latest recommendations of authoritative actors (the EUA and European Commission). Then, we turn our attention to the Finnish context and discuss the latest development phases of Finnish doctoral education. After introducing the Finnish context, we describe our analytical framework by defining doctoral education as a sub-field of higher education policy, and we introduce the concept of policy instruments. In the remaining sections, we present the findings of our study, describing the impact of the European 
recommendations (partly through national steering and use of policy instruments) at the institutional level, using one case example (University of Jyväskylä) to highlight our findings.

\section{Policy background: European recommendations for developing doctoral education}

Over the past 20 years, European universities have employed different approaches to organising their doctoral training. Owing to the differing historical traditions of higher education, the organisation of doctoral programmes has shown great diversity not only across different countries in the European Union (EU) but also between universities within the same country. As recently as 15 years ago, there seemed to be no consensus on how doctoral training could or should be reorganised in the EU (Kivistö 2011). However, the Europe-wide development of doctoral training began to receive considerable emphasis in 2003, when it was explicitly integrated into the development of the European Higher Education Area (the Bologna Process) and the European Research Area. The Communiqué released by the European ministers after their 2003 meeting in Berlin can be seen as a starting point for this shift in attention; it stated that doctoral training should be considered the 'third cycle in the Bologna Process' (Berlin Communiqué 2003, p7). After the Berlin ministerial meeting, the EUA was given a mandate to further explore the key issues facing doctoral training, and to formulate basic recommendations for successful doctoral programmes in Europe.

To obtain further insight into these issues, in 2004 and 2005 the EUA conducted a research project on doctoral programmes in Europe, which addressed the following goals: (1) 'to identify essential conditions for successful doctoral programmes in Europe,' and (2) 'to promote and encourage cooperation in the development of doctoral programmes at the European level' (European University Association 2005, p6). The preliminary results of this 
project were presented in Salzburg, Austria, in 2005, where 10 basic principles for the third cycle were identified (European University Association 2005). The Salzburg Principles were general guidelines that were used in many countries as the basis for national reforms in doctoral education. In general, they addressed the nature of European doctoral education (the requirement of originality of doctoral research, the legitimacy of diversity in doctoral training), institutional responsibilities for doctoral education, duration of doctoral studies, the status of doctoral students as early researchers, and aspects of supervision and funding (Kottmann 2011; European University Association 2007).

The Bergen Communiqué issued at the Minister's Conference in 2005 took up these recommendations, restating that doctoral education was central to linking the European Higher Education Area and the European Research Area. It also specified the role of the EUA in the reform process, as it officially mandated the EUA to work on a report on the development of basic principles for doctoral programmes (Kottmann 2011). In 2010, five years after the establishment of the Salzburg Principles, the EUA conducted a series of consultation events with its members to explore the level of implementation of the Salzburg Principles at European universities. As an outcome of these events, the 'Salzburg II Recommendations' were published (see Table 1). 
- Critical mass and critical diversity: Institutions must develop a critical mass and diversity of research to offer high-quality doctoral education (through more focused research strategies and engagement in larger research networks, collaborations or regional clusters).

- Recruitment, admission and status: Programmes should develop recruitment strategies that correspond to their particular mission and profile. Admissions policies must be transparent and accountable (a single, identifiable place to apply, admissions based on a well-defined public set of criteria). Doctoral candidates should be recognised as early-stage researchers with commensurate rights and duties.

- Supervision must be a collective effort with clearly defined and written responsibilities for the main supervisor, supervisory team, doctoral candidate, doctoral school, research group and institution. Providing professional development to supervisors is an institutional responsibility. Supervisors must be active researchers.

- Outcomes of doctoral research must testify to the originality of the research and be suitable for dissemination.

- Career development for doctoral candidates must take into account individual goals and motivations and acknowledge the wide range of careers. Offering training in transferable skills should be a priority. Building ties to the other sectors contributes to bridging the communication gap with potential employers and recruiters.

- Credits: Applying the credit system is not a necessary precondition for establishing successful doctoral programmes (especially when credits are used to measure the research component or its associated dissemination outputs).

- Quality and accountability: It is necessary to develop specific systems for quality assurance in doctoral education. Assessment of the academic quality of doctoral education should be based on peer review and be sensitive to disciplinary differences. Institutions should develop indicators based on institutional priorities such as individual progression, net research time, completion rate, transferable skills, career tracking and dissemination of research results for early-stage researchers.

- Internationalisation strategies should be a tool in increasing the quality of doctoral education and developing institutional research capacity (internationalisation at home, collaborative doctoral programmes, international joint doctoral programmes, mobility).

- Funding: High-quality doctoral education requires adequate, sustainable and doctorate-specific funding opportunities. Funding schemes that aim to increase the number of doctoral candidates should take into account the quality and capacity of the programmes.

- Autonomy: Institutions need autonomy to be able to establish, and be accountable for, diverse structures with different research strategies and strengths.

- Legal framework: The national and European legal frameworks must give institutions the opportunity to engage in innovative doctoral programmes and to develop their quality assurance systems independently within their national frameworks.

The Salzburg II Recommendations were built on the original Salzburg Principles; they affirmed the validity of the basic principles, and gave them additional, concrete content (European University Association 2010). The recommendations dealt with three different areas: (1) the specific nature of doctoral studies, (2) factors and practices determining the success of doctoral programmes, e.g., recruitment, admission and status of doctoral students or the supervisory organisation, and (3) the main obstacles and problems faced in doctoral education (Kottmann and Weyer 2013).

In 2011, the European Commission developed and published a set of seven principles for innovative doctoral training in the framework of the European Research Area (European Commission 2011). These seven EU principles were based on a review of several 
initiatives-including the Salzburg Principles and Salzburg II Recommendations-that were intended to identify and promote good practices in doctoral training. These principles underlined the importance of research excellence in doctoral training in terms of high academic standards and innovativeness of doctoral research, attractiveness of institutional environments and good working conditions contributing to career development, and the need for interdisciplinary research. The commission also underlined greater exposure to industry and other relevant sectors, international networking, transferable skills training, and the need for special quality assurance practices to verify accountability in all stages of doctoral training.

\section{Doctoral education reforms in Finland}

Before discussing the implementation of the Salzburg II Recommendations in Finland, we first set the stage by outlining the major policy developments in Finnish doctoral education over the past 20 years. In principle, the development of modern Finnish doctoral education can be divided into three distinctive phases: (1) traditional doctoral education (pre-1994), (2) the doctoral programme model (1994-2011) and (3) the doctoral school model (2011present). One can argue that modern doctoral education, as part of the national education system, was established in 1994, and the function of doctoral education has changed from socialising new members of academia to educating experts in order to achieve a knowledgebased society.

The transition of traditional doctoral education culminated with the 1987 OECD country review of Finnish science and technology policy, which stated that doctoral education in Finland was poorly organised (Ahola 2007). As a response to this critique, the government initiated the doctoral programme model (also known as the graduate school 
system) in 1994, and officially launched this model from 1999 to 2011. The doctoral programme model was composed of inter-institutional networked doctoral training financed and coordinated by the Academy of Finland as a targeted tool to expand the volume of doctoral training. The expansion was aimed at fields of importance with respect to the national innovation policy, such as information technology and biotechnology. The development of doctoral training was one of the areas emphasised in Finnish higher education policy (and structural development); therefore, the government paid significant attention to its investment in this area.

The third phase in developing Finnish doctoral education is the doctoral school model, which has been in effect since 2011. The most important document in forming the new model is the 'Ruskoaho Report' (Suomen Akatemia 2011) commissioned by the Academy of Finland. From the perspective of steering practices, the Ruskoaho Report's recommendations can be summarised as follows: First, the responsibility for the development of doctoral education should be placed on universities, not system-level initiatives. Therefore, the quality of doctoral education should also be ensured as part of the regular external quality assurance process of universities. Secondly, each university should have doctoral school(s) coordinating the unit-level doctoral training offered at the universities. Third, universities should be responsible for the content, profiles, quality, quantity and evaluation of their programmes and dissertations. Fourth, funding of doctoral education should be allocated as part of the regular formula funding to universities, not as earmarked grants for specific doctoral programmes. Finally, legislation should allow the termination of the student status of doctoral students, as in the case of prolonged studies, and detailed regulations on dissertations should be abolished from the legislation (as they should fall under the autonomy of universities). 
This latest reform in Finnish doctoral education was the first attempt to restructure national doctoral education within the context of increased university autonomy. Unlike the doctoral programme model, it is not based on a direct funding instrument and network structures; instead, it is founded on the government's use of informational policy instruments and on a sense of trust that the universities can use their autonomy wisely. In addition, the context of the latest reform is different from that of prior developments. In 2009 (effective from 2010), a new Universities Act was passed, changing the legal status of universities from state bureaus to independent legal persons under public or private law (Pekkola and Kivistö 2011; Aarrevaara, Dobson, and Elander 2009; Tirronen and Nokkala 2009; Välimaa 2011).

\section{Framework for analysis: The use of policy instruments in Finnish doctoral education}

As shown by the developments depicted above, doctoral education policies have become more internationalised, owing to the parallel policy questions, and pressures throughout all European countries. This development has partly shifted the responsibility of policy formulation from the national to the international level (Nagel, Martens, and Windzio 2010; Kottmann 2011). However, policy implementation processes and, in particular, the use of specific policy instruments, are still very much bound to differing national contexts and policy traditions. Therefore, policy instruments as 'a set of techniques by which governmental authorities wield their power in attempting to ensure support and effect or prevent social change' (Vedung 1998, p21) are crucial to mediating the goals and effects of policies.

Policy instruments can be categorised as regulative, financial or informational. Regulative instruments include laws, statutes, bills, orders, norms and directives that oblige 
the regulated parties to act in accordance with what is ordered in these rules. Financial instruments, such as various types of funding mechanisms, provide economic incentives (or sanctions) that motivate the parties to act in accordance with the policy goals set by the governmental authority. In contrast, informational instruments influence actors through the transfer of knowledge or persuasive reasoning in the form of policy recommendations, guidelines, and other non-binding policy documents (Bemelmans-Videc, Rist, and Vedung 1998; Young 2012).

In recent years, financial and informational instruments have become increasingly important policy instruments in many higher education systems. This is because using highly restrictive instruments such as laws in an overly detailed manner easily leads to government 'micro-management,' which has proven less effective in achieving expected policy goals. Instead, broader and less detailed regulatory frameworks accompanied by the use of financial and informational instruments, which provide higher education institutions more room for self-regulation, are believed to offer better chances for more effective policies (van Vught and de Boer 2015).

\section{Policy instruments and steering in Finnish doctoral education}

The current model emphasises the role of the university as an autonomous organisation. This is a major change in Finnish doctoral education, as institutional management has in practice, exerted more control over doctoral education. The power of the academic discipline is declining at the expense not only of the government or markets, but also the university bureaucracy. Organisational structures, policies, and best practices are gaining importance, and the disciplinary socialisation process between the master and the novice might be slowly losing its importance. As such, this development is parallel to the wider European 
developments, where policy makers have followed a more utilitarian approach to doctoral education and have started to require universities to develop institutional strategies for doctoral education by taking the rationales of the knowledge-intensive economy into account (Kehm 2006).

For the national steering of doctoral education, the government employs three basic policy instruments: (1) university legislation that remains only a loose framework for degrees (regulative instrument); (2) a funding model that rewards the production of doctoral degrees (10\% of core funding) and, more remotely, publications (13\% of core funding), and competitive research (9\% of core funding) (financial instrument); and (3) development guidelines such as 'Education and Research: A Development Plan 2011-2016' (Ministry of Education and Culture 2012), evaluations and recommendations (informational instruments). Information steering is backed up with performance negotiations and agreements between the Ministry of Education and Culture and the universities, in which the strategic funding of universities is allocated. Table 2 summarises the development and steering of doctoral education. 
Table 2. Overview of development of Finnish doctoral education

\begin{tabular}{|l|l|l|}
\hline \multicolumn{1}{|c|}{ Model } & $\begin{array}{l}\text { Policy instruments used by } \\
\text { steering committees }\end{array}$ & Main steering body \\
\hline $\begin{array}{l}\text { Traditional } \\
\text { (elite) } \\
1994\end{array}$ & $\begin{array}{l}\text { Loose regulative } \\
\text { instruments } \\
\text { Financial instruments } \\
\text { (controlling } \\
\text { expenditures with line- } \\
\text { item budgets) }\end{array}$ & $\begin{array}{l}\text { Ministry of Education } \\
\text { Academy of Finland (personal } \\
\text { grants allocated to researchers) } \\
\text { Parliament (decisions on } \\
\text { university-specific staff } \\
\text { positions) }\end{array}$ \\
\hline $\begin{array}{l}\text { Doctoral } \\
\text { programmes } \\
\text { (New-route PhD) }\end{array}$ & $\begin{array}{l}\text { Loose regulative } \\
\text { instruments } \\
\text { Financial instruments } \\
\text { (direct input-based } \\
\text { funding for graduate } \\
\text { schools, performance- } \\
\text { based funding) }\end{array}$ & $\begin{array}{l}\text { Ministry of Education } \\
\text { Academy of Finland }\end{array}$ \\
\hline $\begin{array}{l}\text { Doctoral school } \\
\text { (New-route PhD) } \\
2011-\text { present }\end{array}$ & $\begin{array}{l}\text { Informational } \\
\text { instruments } \\
\text { (Ruskoaho Report's } \\
\text { recommendations, four- } \\
\text { stage career model, } \\
\text { European } \\
\text { recommendations) } \\
\text { Financial instruments } \\
\text { (performance-based } \\
\text { funding) } \\
\text { Loose regulative } \\
\text { instruments }\end{array}$ & Academy of Finland \\
\hline
\end{tabular}

\section{Policy instruments in use and the implementation of the Salzburg II Recommendations}

\section{Using information as a policy instrument}

The picture of the use of information in steering instruments becomes more comprehensive when we take into account all policy fields that are indirectly related to doctoral education. According to Kehm (2007b), doctoral education is an important link between European higher education and research and innovation policies. This is also the case in Finland, where doctoral education is considered an intrinsic part of the national research policy. In this 
regard, doctoral education is steered by evaluating the level and rank of Finnish science (every three years) and through different types of field-specific ad hoc evaluations. In addition, doctoral education is an important component of Finland's innovation policy. Academic careers are steered by the Ministry of Education in order to ensure enough mobility internationally and nationally between institutions and sectors. Moreover, while the Academy of Finland tracks the employability of $\mathrm{PhD}$ graduates, the Ministry of Economic Affairs and Employment steers innovation policy, and therefore, in part, doctoral education as well. Both policy fields are also influenced by European-level recommendations. In particular, the previously mentioned recommendations from the EUA and European Commission have clearly received system-wide attention from both universities and government bodies (Figure $1)$.

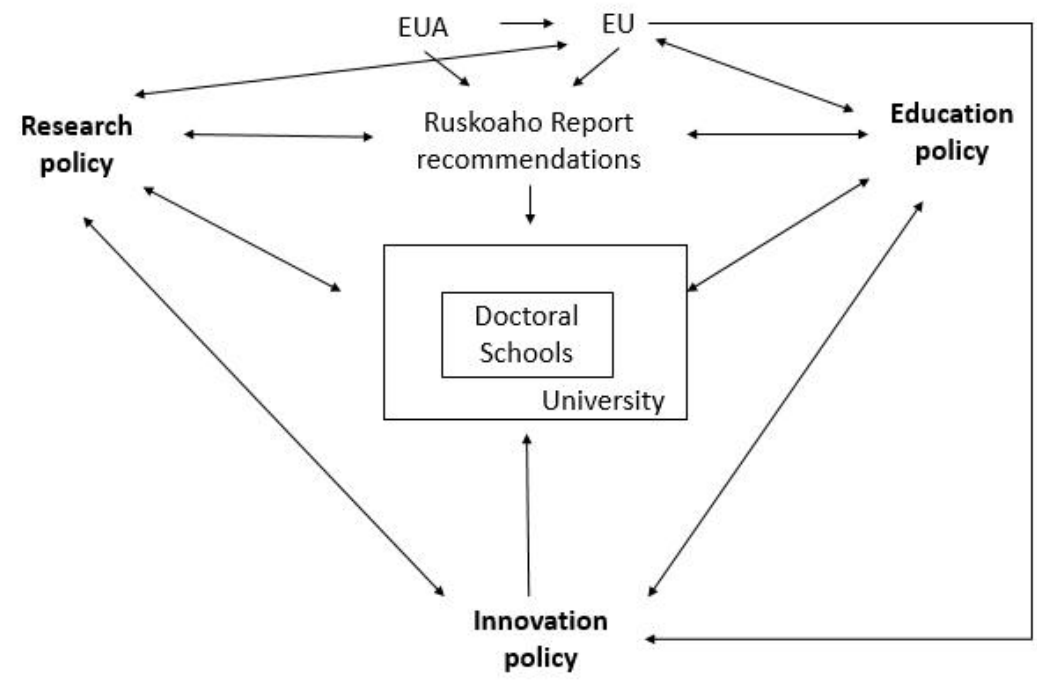

Figure 1. Informational steering impulses

\section{Using finance as a policy instrument}

As mentioned above, performance-based funding is the main financial steering instrument attached to the steering of doctoral education. In the funding formula used by the Ministry of 
Education and Culture, doctoral degrees (and related publications) are counted as part of research productivity. In addition, two other financial instruments support doctoral education directly at the level of research groups. Firstly, the competitive research grants provided by the Academy of Finland (ACAF) offer support for research conducted by doctorates working on Academy-funded research projects. Secondly, operating under the auspices of the Ministry of Economic Affairs and Employment, Tekes (the Finnish Funding Agency for Innovation) also supports doctoral education as part of its funding for research projects. The European Commission also has several funding instruments that can be used directly in doctoral training, such as the Erasmus Mundus Joint Doctorates programme (Figure 2).

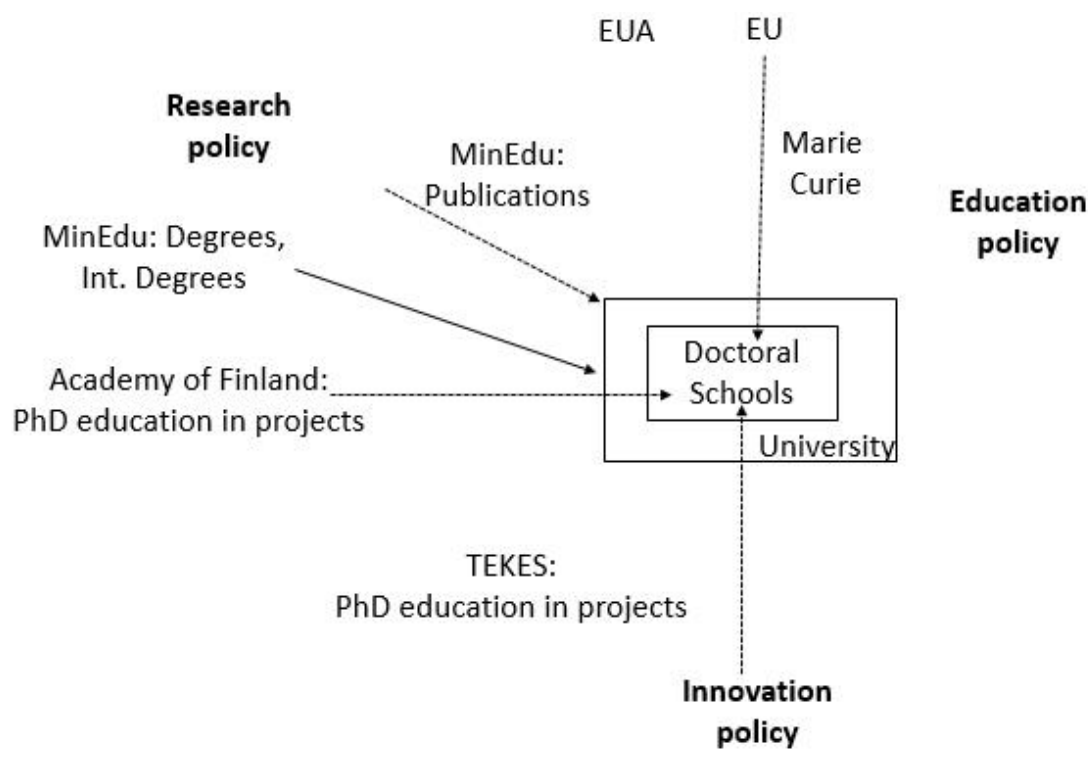

Figure 2. Financial steering impulses

\section{Using regulation as a policy instrument}

The use of statutory policy instruments is almost non-existent, as Finnish university legislation does not contain regulations on doctoral education. Unlike the first- and secondcycle degrees, which are more strongly regulated by legislation, doctoral education is directly 
regulated only by the statute on higher education degrees. This statute provides merely a loose framework for doctoral degrees (dissertations and studies). Educational responsibilities, e.g., the authority of a university to grant degrees in a certain field, are regulated by the same statute. There are no norms regulating the length of studies or the conditions for the expiration of student status (Figure 3).

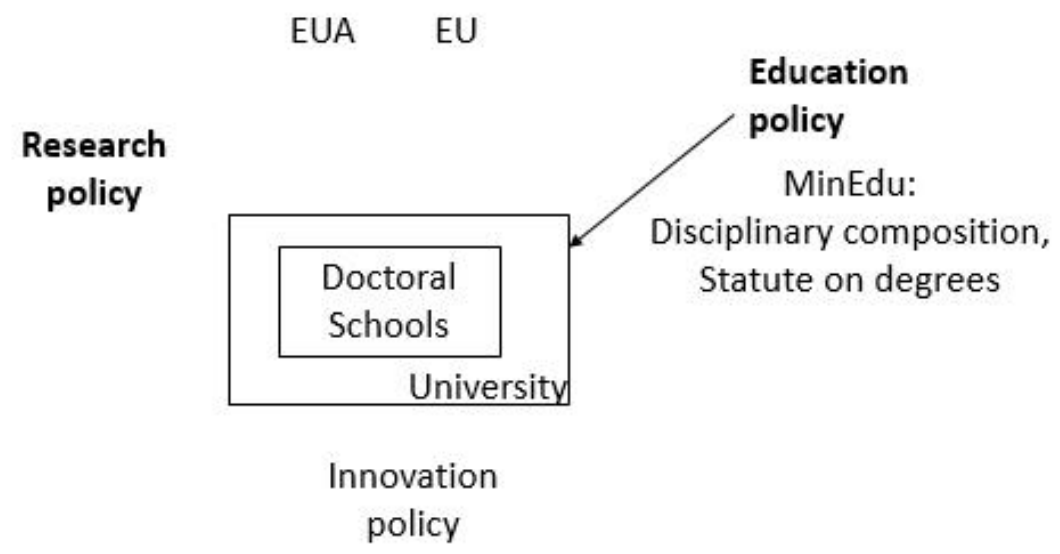

Figure 3. Normative steering impulses

\section{Implementation of Salzburg II Recommendations at the institutional level: The case of the University of Jyväskylä}

Describing system-level policies requires a look at the effects of the reforms at the institutional level. We observe the concrete effects of the latest European developments and national reform in doctoral education through the case example of doctoral education at the University of Jyväskylä (JYU). JYU is a middle-sized multidisciplinary university with seven faculties. In 2014, JYU had 14,648 students, of which 1,684 were doctoral students.

In general, the development of doctoral education at JYU has followed national trends. In 2011, as with many other universities in Finland, JYU restructured its doctoral education into a three-level model, with each organisational level having a designated set of 
responsibilities. The role of the university-wide doctoral school, known as the graduate

school, is to manage doctoral education at the university level. Meanwhile, the doctoral

schools in faculties decide on most of the detailed and practical issues related to running the

doctoral training, including teaching and supervision for students in doctoral programmes

(Table 3).

Table 3. Responsibilities and organisation of doctoral training at the University of Jyväskylä

\begin{tabular}{|c|c|}
\hline Level & Organisation and responsibilities \\
\hline $\begin{array}{l}\text { University of Jyväskylä } \\
\text { (JYU) doctoral school } \\
\text { (graduate school) for } \\
\text { doctoral studies }\end{array}$ & $\begin{array}{l}\text { The doctoral school is led by a vice rector and assisted by a steering } \\
\text { board. } \\
\text { Responsibilities } \\
\text { 1. implementation and content-related development } \\
\text { 2. evaluation and steering, assessing the needs of doctors in all fields } \\
\text { 3. coordination of studies promoting transferable skills } \\
\text { 4. makes proposals to the rector regarding the funding of the graduate } \\
\text { school } \\
\text { 5. makes reports to the rector and the Science Council on the state of } \\
\text { doctoral education } \\
\text { 6. provides information on doctoral education in JYU }\end{array}$ \\
\hline $\begin{array}{l}\text { Faculty-level doctoral } \\
\text { schools } \\
\text { Seven faculties } \\
\text { - Faculty of Education } \\
\text { - Faculty of Humanities } \\
\text { - Faculty of Information } \\
\text { Technology } \\
\text { - Faculty of Mathematics and } \\
\text { Science } \\
\text { - Faculty of Social Sciences } \\
\text { - Faculty of Sport and Health } \\
\text { Sciences } \\
\text { - Jyväskylä University School } \\
\text { of Business and Economics }\end{array}$ & $\begin{array}{l}\text { The faculty-level doctoral schools consist of the doctoral programmes } \\
\text { operating in the faculties. Each faculty's doctoral education is guided } \\
\text { and supervised by the faculty council. The dean (or vice dean) is } \\
\text { responsible for the doctoral education. } \\
\text { Responsibilities } \\
\text { 1. confirm the number of doctoral programmes } \\
\text { 2. approve degree requirements } \\
\text { 3. organise application procedures } \\
\text { 4. enrol new students } \\
\text { 5. confirm supervisors and follow-up groups for doctoral students } \\
\text { 6. appoint pre-examiners and grant permission to defend the } \\
\text { dissertations, assess and approve doctoral dissertations } \\
\text { 7. allocate doctoral student positions and grants } \\
\text { 8. report to the university graduate school } \\
\text { 9. process feedback and appeals }\end{array}$ \\
\hline $\begin{array}{l}\text { Doctoral programmes } \\
19 \text { programmes }\end{array}$ & $\begin{array}{l}\text { One or more doctoral programmes operate in each faculty. The } \\
\text { programmes can be faculty-specific or shared network programs. The } \\
\text { doctoral programmes can differ from their internal rules, e.g., the } \\
\text { composition of operating committees and the content and structure of } \\
\text { the syllabus can vary inside doctoral programmes, but they must follow } \\
\text { the University Graduate School's principles and rules. } \\
\text { Responsibilities } \\
\text { The doctoral programmes participate in student recruitment and offer } \\
\text { teaching and supervision. }\end{array}$ \\
\hline
\end{tabular}


In the following analysis, we aim to provide insight into the implementation of the Salzburg Recommendations at the case university. We analyse all recommendations focusing on activities at the university level (we have omitted the recommendations concerning funding, legal framework, and intersectoral collaboration, which are aimed more at the system level). The analysis is based on an analysis of various internal documents of JYU and information acquired from the JYU graduate school coordinator.

Critical mass and critical diversity. According to the Salzburg Recommendations, institutions must develop a critical mass and diversity of research to offer high-quality doctoral education (through more focused research strategies and engagement in larger research networks, partnerships, or regional clusters). At the institutional level, as part of the selection criteria for doctoral education, the research topic has to be relevant to the faculties' and/or departments' strategies. Furthermore, international connections and mobility are supported, which increases the critical mass and diversity of research. National and international network programmes are important, especially in specific research areas, to increase critical mass and diversity.

Recruitment, admission and status. The Salzburg Recommendations suggest that programmes should develop recruitment strategies that correspond to their particular mission and profile. Admission policies must be transparent and accountable (a single, identifiable place to apply, admission based on a well-defined public set of criteria). Doctoral candidates should be recognised as early-stage researchers, with commensurate rights and responsibilities. In JYU, the recruitment and admission of doctoral students takes place at the faculty level. The recruitment and selection criteria are uniform in every faculty. Furthermore, in JYU's HRS4R ${ }^{1}$ development process, recruitment is one of the areas of

1 HRS4R stands for the Human Resource Strategy for Researchers, the European Commission initiative to support research institutions and funding organisations in 
development. Doctoral candidates who have an employment relationship with the university are still called doctoral students; however, they are treated as staff members, and have the same rights as other staff members (apart from the doctoral students who are working with a grant, who are not entitled to the same benefits, e.g., health insurance, as other faculty members).

Supervision. According to the Salzburg Recommendations, the supervision of doctoral students must be a collective effort, with clearly defined, written responsibilities for the main supervisor, supervisory team, doctoral candidate, doctoral school, research group, and institution. Supervisors must be active researchers, and providing professional development to supervisors is an institutional responsibility. At the JYU, all doctoral students have at least one main supervisor with adequate knowledge and expertise. The JYU's general principles of graduate school for doctoral studies clearly mentions that the faculty's task is to confirm the supervisor and appoint the follow-up group for the doctoral student. The supervisors and students are aware of their responsibilities and agree on the details of supervision as well as the studies, in a written supervisory agreement that is signed by both parties. Together with the supervisory agreement, a personal study plan for each student is agreed on and will be updated and monitored regularly (annually for full-time doctoral students). Moreover, at least one of the supervisors must be a professor, docent or doctoraldegree-holding researcher/teacher from the JYU. It is recommended that supervisors conduct university pedagogical studies, which are offered as staff training in JYU.

Outcomes, quality and accountability. According to the Salzburg Recommendations, the outcomes of doctoral research must testify to the originality of the research, and must be suitable for dissemination. The recommendations also state the necessity of developing

implementing their charter and code. The aim is to make researchers' careers more attractive and to increase mobility in the European Higher Education Area. (See more at http://ec.europa.eu/euraxess/index.cfm/rights/strategy4Researcher.) 
specific systems for quality assurance in doctoral education. The assessment of the academic quality of doctoral education should be based on peer review and be sensitive to disciplinary differences. Institutions should develop indicators based on institutional priorities such as individual progression, net research time, completion rate, transferable skills, career tracking and dissemination of research results for early-stage researchers.

In JYU and other Finnish universities, the originality of the thesis and its suitability for dissemination are verified in several stages. Before a dissertation is sent for preexamination (to two independent reviewers), it will go through an originality check using Urkund software to detect plagiarism. Pre-examiners verify the originality and scientific value of a thesis and give their approval (or disapproval) for the thesis to be presented in a public defence. In the public defence, the opponent will review the scientific merits of the thesis and propose the approval (or disapproval) of the thesis to the faculty council. With regard to quality assurance, doctoral education is evaluated as part of institutional audits conducted by FINEEC. The JYU graduate school is continuously developing doctoral education, and the Science Council is responsible for their evaluation.

Career development. The Salzburg Recommendations also propose that the institutional career support offered for doctoral candidates take into account individual goals and motivations, and acknowledge the wide range of careers for doctorate holders. Offering training in transferable skills, including research ethics, should be a priority. At the institutional level, more detailed recommendations are given. The supervisor and follow-up group are responsible for discussing career development with the doctoral student. Furthermore, the previously mentioned HRS4R process underlines the importance of career planning. JYU offers transferable skills courses to enable doctoral students to recognise their skills and opportunities. Transferable skills courses include discipline-specific skills, research 
skills, communication skills, and skills related to teaching and guidance. By learning these, doctoral students will gain versatile professional expertise.

Credits. According to the Salzburg Recommendations, applying a credit system is not a necessary precondition for establishing successful doctoral programmes (especially when credits are used to measure a research component or its associated dissemination outputs). However, in JYU and other Finnish universities, both the doctoral studies (course work) and the dissertation are quantified by ECTS-credits. At JYU, the faculties define the number of ECTS credits needed to obtain the doctoral degree. However, in all seven faculties, the number of ECTS credits is 240, and doctoral studies range from 30 to 60 ECTS credits. Dissertations are weighted as 180-210 ECTS credits by all these faculties.

Internationalisation strategies. The recommendations should serve as a tool to increase the quality of doctoral education and to develop the institutional research capacity (internationalisation at home, collaborative doctoral programmes, international joint doctoral programmes and mobility). For instance, the JYU recommends in the 'Guide for Doctoral Studies' that doctoral students should participate in international conferences, summer/winter schools, and other international courses, as well as working in research groups abroad. JYU grants funding (Science Council funding) for researchers' mobilisation twice a year so that doctoral students and researchers will have opportunities to build international networks, gain valuable experience working abroad, and improve their communication skills, which are especially necessary when working internationally. With external project funding (JYU occasionally provides funding for visitors), it is possible to request international visitors, which is also valuable for internationalisation.

Autonomy. The Salzburg Recommendations also stress that institutions need distinct research strategies and different strengths. The recommendations also emphasise that the national and European legal framework must give institutions the opportunity to engage in 
innovative doctoral programmes, and to develop their quality assurance systems independently within their national frameworks. Institutions should also have the freedom to develop their own quality indicators that correspond with the standards of the individual disciplines, and with the overall institutional strategy.

JYU and other Finnish universities periodically enter into a contract with the Ministry of Education and Culture (the current contract is for 2013 to 2016), which sets quantitative goals for doctoral degrees, international students and publications. These contracts are negotiated between the university and the Ministry of Education and Culture.

However, the JYU enjoys full autonomy in the development of doctoral education within the relatively loose framework of the national law. JYU and other Finnish universities are fully autonomous in terms of the content and focus of research strategies and positioning. JYU has the freedom to develop the structures and processes of doctoral education without regulatory interference; the same goes for its positioning with respect to other Finnish universities. JYU is also autonomous in deciding the internal quality assurance system within the national quality assurance framework of FINEEC audits. 
Table 4. Implementation of Salzburg II Recommendations and the use of policy instruments at the University of Jyväskylä

\begin{tabular}{|c|c|c|c|c|c|}
\hline \multirow{2}{*}{ Salzburg II } & \multirow{2}{*}{$\begin{array}{l}\text { Realisation based on } \\
\text { JYU planning } \\
\text { documents } \\
\\
\text { (++ Strong realisation) } \\
\text { (+ Realisation) } \\
\text { (- Weak realisation) }\end{array}$} & \multicolumn{3}{|c|}{$\begin{array}{l}\text { Use of policy } \\
\text { instruments }\end{array}$} & \multirow{2}{*}{ Notes } \\
\hline & & 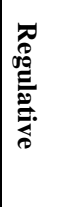 & 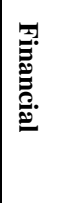 & 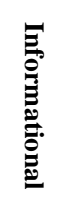 & \\
\hline $\begin{array}{l}\text { Critical mass and } \\
\text { critical diversity }\end{array}$ & ++ & $\mathbf{x}$ & & $\mathbf{x}$ & $\begin{array}{l}\text { The university has been authorised to } \\
\text { grant doctoral degrees in certain } \\
\text { fields of education by national } \\
\text { regulations. }\end{array}$ \\
\hline $\begin{array}{l}\text { Recruitment, } \\
\text { admission and status }\end{array}$ & ++ & & & $\mathbf{x}$ & $\begin{array}{l}\text { No national steering in educational } \\
\text { policy, four-stage career model, } \\
\text { HRS4R }\end{array}$ \\
\hline Supervision & ++ & & & $\mathbf{x}$ & $\begin{array}{l}\text { Information evaluations, Ruskoaho } \\
\text { Report }\end{array}$ \\
\hline Outcomes & + & & $\mathbf{x}$ & & $\begin{array}{l}\text { Published articles are counted as part } \\
\text { of research productivity }\end{array}$ \\
\hline $\begin{array}{l}\text { Quality and } \\
\text { accountability }\end{array}$ & ++ & & $\mathbf{x}$ & & $\begin{array}{l}\text { Nationally, doctoral education is } \\
\text { understood to be a part of university } \\
\text { activities. Accountability is verified } \\
\text { via performance-based funding. } \\
\text { Evaluations focus on enhancement } \\
\text { rather than control. }\end{array}$ \\
\hline Career development & ++ & & $\mathbf{x}$ & $\mathbf{x}$ & $\begin{array}{l}\text { Steered by the four-stage career } \\
\text { model and HRS4R, only financial } \\
\text { incentives are related to the Academy } \\
\text { of Finland grants allocated mostly to } \\
\text { individuals and not to institutions. }\end{array}$ \\
\hline Credits & + & & & & $\begin{array}{l}\text { There are no national regulations } \\
\text { related to study credits. }\end{array}$ \\
\hline $\begin{array}{l}\text { Internationalisation } \\
\text { strategies }\end{array}$ & ++ & & $\mathbf{x}$ & $\mathbf{x}$ & $\begin{array}{l}\text { Steered by the four-stage career } \\
\text { model and HRS4R, financial } \\
\text { incentives are provided for } \\
\text { international doctoral degrees. }\end{array}$ \\
\hline Autonomy & - & $\mathbf{x}$ & & $\mathbf{x}$ & $\begin{array}{l}\text { Universities are autonomous legal } \\
\text { entities. }\end{array}$ \\
\hline Legal framework & ++ & $\mathbf{x}$ & & $\mathbf{x}$ & $\begin{array}{l}\text { Loose legal framework for doctoral } \\
\text { degrees. The Ruskoaho Report } \\
\text { recommends that the norms on } \\
\text { degrees should be loosened but the }\end{array}$ \\
\hline
\end{tabular}




\begin{tabular}{|l|l|l|l|l|l|}
\hline & & & & & $\begin{array}{l}\text { regulation on the right to study } \\
\text { should be strengthened. }\end{array}$ \\
\hline Funding & & $\mathbf{x}$ & & $\mathbf{x}$ & $\begin{array}{l}\text { Funding is mainly steered by } \\
\text { performance-based indicators. No } \\
\text { qualitative measurements/ } \\
\text { evaluations. Recommendations on } \\
\text { equity among students have been } \\
\text { given. }\end{array}$ \\
\hline $\begin{array}{l}\text { Intersectoral } \\
\text { collaboration }\end{array}$ & & & $\mathbf{x}$ & $\begin{array}{l}\text { The role of universities in initiating } \\
\text { collaboration is emphasised and } \\
\text { encouraged. }\end{array}$ \\
\hline
\end{tabular}

Table 4 summarises the implementation of the Salzburg II principles and the use of national policy instruments in the case institution. Although Finnish universities have a long history as public institutions and are still subject to public law, regulation is not the main instrument used to steer doctoral education. In performance-based funding, some aspects of doctoral education are taken into account, although institutional the financial governance of doctoral education is implemented almost entirely by rewarding the production of doctoral degrees. The main instrument used in steering doctoral education is information. In our case institution's documentation, the principles are mostly strongly realised. There does not seem to be a strong relationship between the steering instruments and the realisation of the Salzburg II Recommendations. Thus, the analysis supports the idea that the EU-level recommendations have a direct impact on the institutional policy.

\section{Discussion and conclusion}

The aims and actualisation of the latest Finnish reform in doctoral education seem to be in line with the goals of European policies, both at the system and institutional levels. However, we cannot conclude that the Finnish policy goals are connected with the government policy instruments in use. Surprisingly, regulative and financial instruments, which can both be 
considered 'strong' instruments in terms of their impact, have provided little support for the realisation of the European-level recommendations. Nevertheless, with respect to informational policy instruments, the practised steering seems to be aimed at promoting the European recommendations. The impact of the recommendations from the EUA or other European actors can be clearly seen in the national-level reports and evaluations that incorporate various recommendations related to doctoral education, such as the ones from the Academy of Finland (Suomen Akatemia 2011) and FINEEC (Niemi et al. 2011). In addition, the current emphasis on strengthening the autonomy of universities is in accordance with the European recommendations.

These observations are in line with some of the views related to 'multi-level governance,' where the positions and resources of various actors frame their actual capabilities to influence policies. Many stakeholders can participate in policy processes; however, not all are able to exert control over the outputs and implementation of these processes (Fumasoli 2015; Bache 2008). Fumasoli (2015) argued that increasing the autonomy of universities across European countries has made them prone to play a more active role in their proactive development activities. Universities often link themselves directly with European-level developments and bypass occasionally slower-paced government initiatives in implementing new ideas. From this vantage point, the informational instrument has become a more effective tool for government steering, as it can be used to reinforce the signals of other stakeholders (such as the EUA and European Commission) when they are considered to be in line with national policy interests. 


\section{Disclosure statement}

No potential conflict of interest was reported by the authors.

\section{Notes on contributors}

Dr. Jussi Kivistö holds positions of University Lecturer and Docent at Higher Education Group, Faculty of Management, University of Tampere, Finland. Kivistö is a coordinator of the Finnish Master's Degree Programme in Higher Education Administration and Management (KOHAMA) and teaches and coordinates several courses in the Erasmus Mundus programme Master in Research and Innovation in Higher Education (MaRIHE). His research interests are related to funding of higher education, higher education governance and higher education policy from which he has published around 60 publications. Among the several third mission activities, Kivistö has served as a consultant for the World Bank.

Dr. Elias Pekkola holds a position of University Lecturer at the Faculty of Management, University of Tampere, Finland. Pekkola acts as a principal investigator of a Finnish research team in project "Effects of changes in leadership and management structures in Nordic HE" funded by the Research Council of Norway (2014-2017). and leads Finnish team in European Commission funded project "Modernisation of Higher Education Institutions through enhancement of Human Resources Management function (HRMinHEI)" funded by Erasmus + (2016-2018). Pekkola's publications include several articles and books on academic work, academic profession, careers and HR-policy perticularly in Finnish context. Pekkola serves also as an academic coordinator of "Nordic Master Programme in Innovative Governance and Public Management". He has acted in various expert roles in Finland and in international projects on academic work, careers and higher education policy.

Ms. Taru Siekkinen is a project researcher and a $\mathrm{PhD}$ student at the Finnish Institute for Educational Research, University of Jyväskylä. Siekkinen has been working in different projects related to higher education since 2012. Her last two projects have been focusing on academic careers: the evaluation project of a four-stage career model in Finnish Universities (funded by the Finnish Ministry of the Education and Culture) 
and careers in Finnish Universities (funded by the Finnish Work Environment Fund). Currently Siekkinen is working in a project "Exiting academics in Networked Knowledge Societies" (2016-2020) is funded by the Academy of Finland. Siekkinen's research interests are related to academic work and careers, academic profession and higher education policy.

\section{References}

Aarrevaara, T., I. R. Dobson, and C. Elander. 2009. "Brave New World - Higher Education Reform in Finland." Higher Education Management and Policy 21 (2): 89-106.

Ahola, S. 2007. "Doctoral Education in Finland: Between Traditionalism and Modernity." In The Doctorate Worldwide, edited by S. Powell and H. Green, 29-39. Berkshire, England: Society for Research into Higher Education, Open University Press and McGraw-Hill.

Auriol, L. 2010. "Careers of Doctorate Holders: Employment and Mobility Patterns." STI Working Paper 2010/4: Statistical Analysis of Science, Technology and Industry, OECD, Paris.

Bache, I. 2008. "Europeanisation and Multi-Level Governance: Empirical Findings and Conceptual Challenges.” Arena Working Paper 16/08, University of Oslo, Norway.

Bemelmans-Videc, M. L., R. C. Rist, and E. Vedung. 1998. "The Sermon: Information Programs in the Public Policy Process—Choice, Effects, and Evaluation.” In Carrots, Sticks, and Sermons: Policy Instruments and Their Evaluation, edited by M. L. Bemelmans-Videc, R. C. Rist, and E. Vedung, 103-128. New Brunswick, NJ: Transaction.

Berlin Communiqué. 2003. "Realising the European Higher Education Area." Accessed 25 November 2016. http://www.ond.vlaanderen.be/hogeronderwijs/bologna/documents/mdc/berlin_comm unique1.pdf. 
Dill, D. D., S. K. Mitra, H. Siggaard Jensen, E. Lehtinen, T. Mäkelä, A. Parpala, H. Pohjola, M. A. Ritter, and S. Saari. 2006. PhD Training and the Knowledge-Based Society: An Evaluation of Doctoral Education in Finland. Helsinki: Finnish Higher Education Evaluation Council.

European Commission. 2011. "Report of Mapping Exercise on Doctoral Training in Europe: Towards a Common Approach." 27 June 2011. European Commission. Accessed 25 November 2016.

http://ec.europa.eu/euraxess/pdf/research_policies/Report_of_Mapping_Exercise_on_ Doctoral_Training_FINAL.pdf.

European University Association. 2005. "Doctoral Programmes for the European Knowledge Society: Final Report." European University Association. Accessed 25 November 2016.

http://www.eua.be/eua/jsp/en/upload/Doctoral_Programmes_Project_Report.1129278 878120.pdf.

European University Association. 2007. "Doctoral Programmes in Europe's Universities: Achievements and Challenges." European University Association. Accessed 25 November 2016. http://rodos.edu.rs/wpcontent/uploads/2014/11/Doctoral_Programmes_in_Europe_s_Universities-1.pdf.

European University Association. 2010. "Salzburg II Recommendations: European Universities' Achievements since 2005 in Implementing The Salzburg Principles." European University Association. Accessed 25 November 2016. http://www.eua.be/Libraries/publications-homepagelist/Salzburg_II_Recommendations.

Fumasoli, T. 2015. "Multi-Level Governance in Higher Education Research." In The Palgrave International Handbook of Higher Education Policy and Governance, edited by J. Huisman, H. de Boer, D. Dill, and M. Souto-Otero, 76-94. Basingstoke: Palgrave Macmillan.

Kehm, B. M. 2006. "Doctoral Education in Europe and North America: A Comparative Analysis." In The Formative Years of Scholars, edited by U. Teichler, 67-78. Portland Press: London. 
Kehm, B. M. 2007a. "Doctoral Education in Europe." In Towards a Multiversity? Universities between Global Trends and National Traditions, edited by G. Krücken, C. Castor, A. Kosmützky, and M. Torka, 132-153. Bielefeld: Transcript Verlag.

Kehm, B. M. 2007b. "Quo Vadis Doctoral Education? New European Approaches in the Context of Global Changes." European Journal of Education 42 (3): 307-319.

Kivinen, O., S. Ahola, and A. Kokko. 1999. "PhD Training in Finland: Problems and Prospects." In Towards the European Model of Postgraduate Training, edited by O. Kivinen, S. Ahola, and P. Kaipainen, 51-81. Turku: University of Turku.

Kivistö, J. 2011. "Developing Doctoral Education in EU and in Finland: Using the U.S. System as a Benchmark." In Higher Education Reforms in Finland and China, edited by Y. Cai and J. Kivistö, 193-210. Tampere: Tampere University Press.

Kottmann, A. 2011. "Reform of Doctoral Training in Europe." In Reform of Higher Education in Europe, edited by J. Enders, H. F. de Boer, and D. F. Westerheijden, 29-43. Rotterdam: Sense.

Kottmann, A., and E. Weyer. 2013. "Exploration of the Implementation of the Principles for Innovative Doctoral Training in Europe: Final Report." European Commission. $\begin{array}{llll}\text { Accessed } & 25 & \text { November }\end{array}$ http://ec.europa.eu/euraxess/pdf/research_policies/IDT\%20Final\%20Report\%20FINA L.pdf.

Ministry of Education and Culture. 2012. "Education and Research 2011-2015: Reports of the Ministry of Education and Culture, Finland 2012:3." Ministry of Education and $\begin{array}{llll}\text { Culture. } & \text { Accessed } & 25 & \text { November }\end{array}$ http://www.minedu.fi/export/sites/default/OPM/Julkaisut/2012/liitteet/okm03.pdf.

Nagel, A. K., K. Martens, and M. Windzio. 2010. "Introduction - Education Policy in Transformation." In Transformation of Education Policy - The Impact of the Bologna Process and the PISA Study in Comparative Perspective, edited by K. Martens, A. K. Nagel, M. Windzio, and A. Weymann, 3-27. Basingstoke: Palgrave.

Niemi, H., H. Aittola, V. Harmaakorpi, O. Lassila, S. Svärd, J. Ylikarjula, K. Hiltunen, and K. Talvinen. 2011. Tohtorikoulutuksen rakenteet muutoksessa. Tohtorikoulutuksen kansallinen seuranta-arviointi. Helsinki: Korkeakoulujen arviointineuvosto. 
Opetusministeriö. 2008. Neliportainen tutkijanura. Opetusministeriön työryhmämuistioita ja selvityksiä 2008:15. Helsinki: Opetusministeriö. Accessed 25 November 2016. http://www.minedu.fi/OPM/Julkaisut/2008/liitteet/tr15.pdf.

Pekkola, E., and J. Kivistö. 2011. "Reforming the Finnish University System: Policies and Institutional Responses." In Leadership and Governance in Higher Education Handbook for Decision-Makers and Administrators, edited by B. Sjur, E. EgronPolak, J. Kohler, L. Purser, and M. Vukasović, 87-106. Berlin: Raabe Verlag.

Suomen Akatemia. 2011. “Tavoitteeksi laadukas, läpinäkyvä ja ennakoitava tohtorikoulutus. Suomen Akatemian asettaman tutkijakoulutukiryhmän ehdotukset tohtorikoulutuksen ja tutkijakoulujärjestelmän kehittämiseksi.” Suomen Akatemia. Accessed 25 November 2016. http://www.aka.fi/globalassets/awanhat/documents/tiedostot/liitetiedostot/tohtorikoulu tus_joulukuu_2011.pdf.

Tirronen, J., and T. Nokkala. 2009. "Structural Development of Finnish Universities: Achieving Competitiveness and Academic Excellence." Higher Education Quarterly 63 (3): 219-236.

van Vught, F., and H. de Boer. 2015. "Governance Models and Policy Instruments." In The Palgrave International Handbook of Higher Education Policy and Governance, edited by J. Huisman, H. de Boer, D. Dill, and M. Souto-Otero, 57-75. Basingstoke: Palgrave Macmillan.

Vedung, E. 1998. "Policy Instruments: Typologies and Theories." In Carrots, Sticks, and Sermons: Policy Instruments and Their Evaluation, edited by M. L. BemelmansVidec, R. C. Rist, and E. Vedung, 21-58. New Brunswick, NJ: Transaction.

Välimaa, J. 2011. "Uusi yliopistolaki ja kansallisen yliopistolaitoksen yhtiöittäminen.” In Koulutus yhteiskunnan muutoksissa: jatkuvuuksia ja katkoksia, edited by J. Lasonen and J. Ursin, 43-93. Jyväskylä: Suomen kasvatustieteellinen seura.

Young, M. 2012. "Multi-Level Steering and Institution Building: The European Union's Approach to Research Policy.” European Educational Research Journal 11: 570-585. doi:10.2304/eerj.2012.11.4.570. 